\title{
Trust me! Examining the contractual relationships between sugarcane producers and mills in the Cerrado
}

\section{Confie em mim! Examinando as relações contratuais entre produtores de cana-de-açúcar e moinhos no Cerrado}

\author{
Brandon H. McKee \\ brandonmckee@ufl.edu \\ Graduando em Economia de Recursos Alimentares e da Universidade da Flórida
}

\section{Ana Claudia Sant'Anna}

acsantanna@ksu.edu

Pós-doutorado no Departamento de Economia Agrícola, Ambiental e de Desenvolvimento da Universidade Estadual de Ohio.Doutora em Economia é da Universidade Estadual de Kansas, Mestre em Economia Aplicada da Universidade de São Paulo (USP), Bacharela em Economia é da Universidade de Brasília (UNB)

\section{Jason S. Bergtold}

bergtold@ksu.edu

Professor e diretor de pós-graduação do Departamento de Economia Agrícola da Universidade Estadual de Kansas, Mestre em Economia Agrícola e Aplicada e PhD em Economia pela Virginia Tech e Bacharel em Economia pela Colorado State University

\section{Marcellus M. Caldas}

caldasma@ksu.edu

Professor associado no Departamento de Geografia da Universidade Estadual de Kansas

Doutorado em Geografia pela Michigan State University, Mestre em Economia Agrícola pela Universidade Federal de Viçosa (UFV) e Bacharel em Economia pela Pontifícia Universidade Católica.

\section{Gabriel Granco}

ggranco@ksu.edu

Pós-doutorando no Stroud Water Research Center, Doutorado em Geografia pela Universidade Estadual do Kansas, Bacharel em Economia e mestre em Economia Aplicada na Universidade de São Paulo, Faculdade de Agricultura Luiz de Queiroz

Recebido em : 15/09/2017

Aprovado em: 10/11/2017
Revista do Programa de Pós-Graduação em Extensão Rural (UFV) 


\title{
RESUMO
}

O aumento na demanda por biocombustíveis aliado às políticas públicas têm promovido a expansão da cana no Cerrado, especialmente em Goiás e Mato Grosso do Sul. As especificidades geográficas, temporais e físicas dos ativos limita a área de onde advem a cana, tornando usinas e produtores dependents uns nos outros. Com isso, contratos são uma prática comum no setor sucroalcoleiro e seu sucesso tem consequências diretas para a sustentabilidade da expansão da cana no Cerrado. Preenchemos, neste estudo, a lacuna na literatura sobre a aceitação de contratos e confiança, determinando os fatores que alteram a percepção do produtor quanto ao contrato e quanto à confiança na usina. Usando dados primários de Goiás e Mato Grosso do Sul estimamos modelos logit ordenados usando as percepções e características dos produtores e de seus estabelecimentos. Lucro e tradição foram identificados como importantes para a aceitação de um contrato. Comunicação, transparência e a opinião demais produtores foram importantes fatores no desenvolvimento de confiança na usina. Logo, usinas que querem melhorar suas a aceitação de seus contratos devem se esforçar em participar mais na comunidade local e na melhoria da comunicação com os fazendeiros.

Palavras Chave: Brasil; Contratos; Etanol; Expansão da cana; Usinas; Confiança

\begin{abstract}
An increase in biofuel demand aligned with public policies has fueled the expansion of sugarcane into Goiás and Mato Grosso do Sul in the Cerrado. Geographic, temporal and physical asset specificities delimit the area from which mills can procure sugarcane, making sugarcane producers and mills dependent on each other. Thus contracting is a common practice in sugarcane production in the Cerrado and its success directly impacts the sustainability of the ethanol expansion. We fill a gap in the literature on producers' contract acceptance and trust by determining the factors that affect contract perception and trust with contractors. Using primary data from the states of Goiás and Mato Grosso do Sul we estimate ordered logit models using producer's perceptions, their characteristics and that of their enterprise. Profits and experience are important factors for a producer when considering a contract. Communication, transparency and other farmer's perception of a mill were important in building trust. Mills wanting to improve their chances of signing a contract should focus on more participation in the community and on better communication with farmers.
\end{abstract}

Keywords: Brazil; Contracts; Ethanol; Sugarcane expansion; Ethanol plants; Trust 


\section{Introduction}

An increase in biofuel demand aligned with public policies has fueled the expansion of sugarcane, sugar and ethanol production into the states of Goiás and Mato Grosso do Sul in the Brazilian Cerrado. This region has experienced an increase of 40 sugarcane operating mills between 2000 and 2012 (Procana 2013), as well as, an increase in their participation in the nation's sugarcane production, from $2 \%$ in 2000 to $10 \%$ in 2013 (IBGE 2014). With the intent of promoting sugarcane expansion, the Sugarcane Agroecological Zoning, launched in 2010, mapped over 22 million hectares in Goiás and Mato Grosso do Sul as suitable for sugarcane production (Manzatto et al. 2009). Geographic, temporal and physical asset specificities delimit the area from which mills can procure sugarcane, making sugarcane producers and mills dependent on each other (Moraes and Zilberman, 2014). Thus, sugarcane producers in this region heavily rely and trust upon their contractual agreements with their local sugarcane mill (Sant'Anna, Bergtold et al. 2016).

Limiting factors associated with sugarcane production have increased producers' reliance upon contractual agreements with mills and, likewise, the mills look to their contractual agreements with producers to maintain the flow of production. The most important limitation is sugarcane's dependency on a speedy harvest-to-processing cycle, as sugarcane begins to lose sucrose 72 hours after harvest (Sant'Anna, Bergtold, et al. 2016). Such limiting factors can be partially overcome by effective management of partnerships through contracts (Vavra, 2009). The advantage of contract farming is that it encompasses the three-part process of internationalization in agriculture, including: production, capital, and trade (Singh, 2000). Contracts can streamline and enhance production, making it advantageous for producers and for dealing with our increasing population. Limiting factors in production agriculture could be potentially be overcome through market coordination and cooperation.

Brazilian sugarcane producers can enter into a variety of agreements with mills, including land rental, agricultural partnership, and supply contract agreements. Land rental contracts provide the local mill with land for sugarcane production for a fixed value paid to the producer or landowner. Agricultural partnership agreements give the local mill use of the land for a percentage of the sugarcane production. Supply contracts allow farmers to produce and sell sugarcane to the local mill. These agreements help Brazilian producers overcome issues of market consolidation, trade fluctuations, and developments 


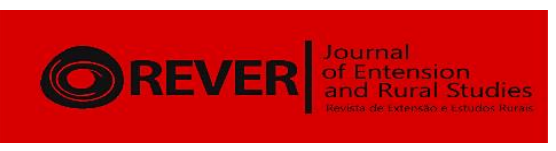

in technology, policy, and the environment (Sant'Anna, Granco, et al. 2016). In terms of the government, motivating contractual agreements may be a way of guaranteeing the sustainability of ethanol production in the Cerrado region.

Contracting brings a host of benefits including, not only, governance between parties, but also, encouraging market efficiency and co-ordination for those in agreement. However, the presence of asymmetric information may allow for the abuse of market power, by obstructing sales and sugarcane quality information (Sant'Anna, Shanoyan, et al., 2016). Given the importance of contracts for sugarcane expansion in the Cerrado, it becomes imperative to understand the relationship between sugarcane producers and processors. As mentioned by Schippmann and Qaim (2011) there is a gap in the literature in studies that provide a more holistic view of how producers perceive contracts and of their trust in contractors. Therefore, the purpose of this study is to evaluate producer trust in the sugarcane mills they contract with and explore factors that impact producer perceptions about their contracts. We examine the contractual attributes, operational characteristic, and socio-economic factors that affect producers' perception of a mill's management and of their contractual relationships. To understand the contractual relationships between sugarcane suppliers, landowners and mills in the Cerrado states of Mato Grosso do Sul and Goiás, where sugarcane expansion has been more intense, we focus on three topics: producers' view of their contract agreements, producers' perception of contract fulfillment, and producers' trust of a mill's management and their direction.

\section{Data and Methods}

\section{Survey Data}

This study was conducted using survey information gathered from 22 counties in Brazil located in the states of Goiás (GO) and Mato Grosso do Sul (MS). These counties were selected based upon the following criteria: (1) geographic location of sugarcane production in 2012 based on the National Institute of Space Research's Canasat project (Rudorff et al. 2010); and (2) the Brazilian county level agricultural production survey showing the growth of sugarcane production (IBGE, 2014). The survey was collected through face-to-face interviews with landowners and sugarcane producers. The survey design was based upon similar studies that were conducted in Quirinopolis, Goiás (Picanço Filho and Marin 2012; Picanço Filho and Marin 2012a; Picanço Filho 2010). Experts and local farmers reviewed and tested the validity of the survey. 
The producers interviewed were from sugarcane grower's associations, Rural Syndicates, and the Goiás and Mato Grosso do Sul Federation of Agriculture and Livestock. The survey included questions on producer demographics, characteristics of farms, landownership, sugarcane production, contracts, and perceptions on sugarcane mills' community interaction.

In 2014, 148 landowners and producers were interviewed, from which 103 were producers currently involved in a contractual agreement with a local sugarcane mill. A limitation of the survey data collected is that it does not represent the entire population of Brazilian agricultural producers. Survey respondents were primarily larger commercial producers that would likely be approached by mills to sign contractual agreements. Since the participants were selected from sugarcane grower associations and other like-wise groups this means the survey population was primarily commercial farms, which tend to be larger in size. The average farm size for the participants in this study was 913 hectares, while the 2006 Brazilian agricultural census indicated an average size of 415 hectares for producers in Goiás and Mato Grosso do Sul (IBGE, 2006). This difference is attributed to our commercial farmer sample group. The landowners' gender proportions between the census and this study were similar, with a $92 \%$ male distribution for the census and a 96\% male distribution for the study. Our study had a higher percentage of farmers with a high school and college degrees than that of the census, $37 \%$ of participants with high school degree and $28 \%$ of undergraduate. The census indicated that only $4 \%$ of farmers completed high school and 3\% college. As well, CONAB (2013) reported the average sugarcane yield of 70.30 tons/ha for this region, while our participants reported a yield of 87.71 tons per a hectare.

For this study four dependent variables and 21 independent variables were used to evaluate the factors that influence producers' business decisions and their trust in local mills and their associated management. Table 1 provides a description of the dependent variables and how they are measured. The dependent categorical variables are measured on a Likert-type scale of one (strongly disagree) to five (strongly agree). The questions gauge the degree of agreeance producers feel towards the statement and evaluate the producers' perception about their contract and relationship with the mill. 
Table 1 - Description of dependent variables

\begin{tabular}{|c|c|c|}
\hline Variable & Likert-Scale & Description \\
\hline Obj & $\begin{array}{l}\text { Strongly Disagree (1) - } \\
\text { Strongly Agree (5) }\end{array}$ & $\begin{array}{l}\text { "I wish I could accomplish my objectives without } \\
\text { a contract with the mill" }\end{array}$ \\
\hline Fulfill & $\begin{array}{l}\text { Yes, a great deal (1) - No, } \\
\text { never (5) }\end{array}$ & $\begin{array}{l}\text { "Do you feel the mill has not fulfilled its side of } \\
\text { the contract" }\end{array}$ \\
\hline Manage & $\begin{array}{l}\text { Strongly Disagree (1) - } \\
\text { Strongly Agree (5) }\end{array}$ & "I trust the management of the mill" \\
\hline Direct & $\begin{array}{l}\text { Strongly Disagree (1) - } \\
\text { Strongly Agree (5) }\end{array}$ & $\begin{array}{l}\text { "I always trust the direction of the mill will do as } \\
\text { promised" }\end{array}$ \\
\hline
\end{tabular}

Source: Survey applied.

Table 2 shows the measurement and description for the 21 independent variables that were used in the empirical analyses. Apart from production (Sales) and contracts types (Land Rental (Con $L R$ ), Agricultural Partnership (Con $A P$ ) and Supply (Base case)), this study also included explanatory variables on producers' market preferences $\left(F_{1}-\right.$ $\left.F_{7} ; M_{1}-M_{5}\right)$ and socioeconomic factors such as location (Loc MS), income level (Inc), and years of experience $(\text { Year })^{1}$.

Table 2. Description of independent variables.

\begin{tabular}{|c|c|c|}
\hline Variable & Measure & Description \\
\hline \multicolumn{3}{|c|}{ Independent Categorical Variables } \\
\hline$F_{1}$ & $\begin{array}{l}\text { Likert-Scale: Strongly Disagree } \\
\text { (1) - Strongly Agree (5) }\end{array}$ & $\begin{array}{l}\text { "A good relationship with the local mill is } \\
\text { important for my business" }\end{array}$ \\
\hline$F_{2}$ & $\begin{array}{l}\text { Likert-Scale: Strongly Disagree } \\
\text { (1) - Strongly Agree (5) }\end{array}$ & $\begin{array}{l}\text { "I would prefer to sign a contract with a farmer } \\
\text { cooperative/association rather than the local mill" }\end{array}$ \\
\hline$F_{3}$ & $\begin{array}{l}\text { Likert-Scale: Strongly Disagree } \\
\text { (1) - Strongly Agree (5) }\end{array}$ & $\begin{array}{l}\text { "I would prefer to sign a contract with a national } \\
\text { owned company rather than a foreign owned } \\
\text { company" }\end{array}$ \\
\hline
\end{tabular}

\footnotetext{
${ }^{1}$ The life of the farm was considered as years of experience. An older farm with a long history could signal a potentially strong tradition in doing things a certain way.
} 


\begin{tabular}{|c|c|c|}
\hline$F_{4}$ & $\begin{array}{l}\text { Likert-Scale: Strongly Disagree } \\
\text { (1) - Strongly Agree (5) }\end{array}$ & $\begin{array}{l}\text { "Without a contract it is hard for a sugarcane } \\
\text { grower to operate in this region" }\end{array}$ \\
\hline$F_{5}$ & $\begin{array}{l}\text { Likert-Scale: Strongly Disagree } \\
\text { (1) - Strongly Agree (5) }\end{array}$ & $\begin{array}{l}\text { "Farmers in the region feel they cannot trust the } \\
\text { local mill" }\end{array}$ \\
\hline$F_{6}$ & $\begin{array}{l}\text { Likert-Scale: Strongly Disagree } \\
\text { (1) - Strongly Agree (5) }\end{array}$ & $\begin{array}{l}\text { "It is difficult to sign a contract with the local } \\
\text { mill" }\end{array}$ \\
\hline$F_{7}$ & $\begin{array}{l}\text { Likert-Scale: Strongly Disagree } \\
\text { (1) - Strongly Agree (5) }\end{array}$ & $\begin{array}{l}\text { "Farms closer to local mills have higher } \\
\text { bargaining power when signing a contract" }\end{array}$ \\
\hline$M_{1}$ & $\begin{array}{l}\text { Likert-Scale: Strongly Disagree } \\
\text { (1) - Strongly Agree (5) }\end{array}$ & $\begin{array}{l}\text { "My profits have decreased since signing the } \\
\text { contract with the mill" }\end{array}$ \\
\hline$M_{2}$ & $\begin{array}{l}\text { Likert-Scale: Strongly Disagree } \\
\text { (1) - Strongly Agree (5) }\end{array}$ & $\begin{array}{l}\text { "Due to the contract I have a more constant } \\
\text { income" }\end{array}$ \\
\hline$M_{3}$ & $\begin{array}{l}\text { Likert-Scale: Strongly Disagree } \\
\text { (1) - Strongly Agree (5) }\end{array}$ & "It is difficult to communicate with the mill" \\
\hline$M_{4}$ & $\begin{array}{l}\text { Likert-Scale: Strongly Disagree } \\
\text { (1) - Strongly Agree (5) }\end{array}$ & $\begin{array}{l}\text { "I am familiar with the business conducted by the } \\
\text { mill: who they sell to, their management } \\
\text { philosophy and practices" }\end{array}$ \\
\hline$M_{5}$ & $\begin{array}{l}\text { Likert-Scale: Strongly Disagree } \\
\text { (1) - Strongly Agree (5) }\end{array}$ & $\begin{array}{l}\text { "I receive a "fair" value for my sugarcane bought } \\
\text { by the mill" }\end{array}$ \\
\hline \multicolumn{3}{|c|}{ Independent Indicator Variables } \\
\hline $\operatorname{Con}_{L R}$ & No (0) or Yes (1) & $\begin{array}{l}\text { A binary variable indicating whether the respondent } \\
\text { has a land rental contract }\end{array}$ \\
\hline $\operatorname{Con}_{A P}$ & No $(0)$ or Yes (1) & $\begin{array}{l}\text { A binary variable indicating whether the } \\
\text { respondent has an agricultural-partnership } \\
\text { contract }\end{array}$ \\
\hline$L o c_{M S}$ & No $(0)$ or Yes (1) & $\begin{array}{l}\text { A binary variable indicating whether the } \\
\text { respondent produces in Mato Grosso do Sul. }\end{array}$ \\
\hline Und & No $(0)$ or Yes (1) & $\begin{array}{l}\text { A binary variable indicating whether the producer } \\
\text { understands their contract agreement }\end{array}$ \\
\hline Late & No $(0)$ or Yes (1) & $\begin{array}{l}\text { A binary variable indicating whether the producer } \\
\text { has received a late payment before }\end{array}$ \\
\hline
\end{tabular}




\begin{tabular}{|c|c|c|}
\hline Inc & $\$ \mathrm{R}$ & Current total household income \\
\hline Mills & Number of Mills & $\begin{array}{l}\text { Number of mills available to producers in their } \\
\text { region }\end{array}$ \\
\hline Year & $\begin{array}{l}\text { Current Year Minus Year } \\
\text { Indicated }\end{array}$ & How long the farm has been in the family. \\
\hline Sales & Percentage (0 to 100$)$ & $\begin{array}{l}\text { Percentage producers indicated of their total sales } \\
\text { that comes from sugarcane production }\end{array}$ \\
\hline
\end{tabular}

Table 3 to 7 give the frequency distributions of the dependent and independent variables included in this study. Sample size, mean, and the standard deviation for each variable is also provided in tables 3 to 7 . The frequency percentages were included for indicators variables. The sample size is based on completed responses from survey respondents. Those who chose not to respond to a question were excluded from the sample.

Table 3 - Descriptive statistics for dependent variables

\begin{tabular}{|c|c|c|c|c|c|c|c|c|}
\hline $\begin{array}{c}\text { Variabl } \\
\mathrm{e}\end{array}$ & $N$ & $\begin{array}{c}\text { Mea } \\
\mathrm{n}\end{array}$ & $\begin{array}{c}\text { Standar } \\
\text { d } \\
\text { Deviati } \\
\text { on }\end{array}$ & $\begin{array}{l}\text { Yes, a } \\
\text { great } \\
\text { deal } \\
(\%)\end{array}$ & $\begin{array}{c}\text { Yes, a } \\
\text { moderat } \\
\mathrm{e} \\
\text { amount } \\
(\%)\end{array}$ & $\begin{array}{c}\text { Occasional } \\
\text { ly } \\
(\%)\end{array}$ & $\begin{array}{c}\text { Rarel } \\
\mathrm{y} \\
(\%)\end{array}$ & $\begin{array}{l}\text { No, } \\
\text { Never } \\
(\%)\end{array}$ \\
\hline Fulfill & $\begin{array}{c}10 \\
0\end{array}$ & 4.6 & 0.9 & 2 & 3 & 7 & 10 & 78 \\
\hline
\end{tabular}

Source: Survey applied.

Observations: Frequencies are displayed as percentages. Percentage values have been rounded and may not add up to $100 \%$.

Table 4 - Descriptive statistics for the other dependent variables

\begin{tabular}{lcccccccc}
\hline $\begin{array}{c}\text { Variabl } \\
\mathrm{e}\end{array}$ & $N$ & $\begin{array}{c}\text { Mea } \\
\mathrm{n}\end{array}$ & $\begin{array}{c}\text { Standard } \\
\text { Deviatio } \\
\mathrm{n}\end{array}$ & $\begin{array}{c}\text { Strongly } \\
\text { Disagree } \\
(\%)\end{array}$ & $\begin{array}{c}\text { Disagree } \\
(\%)\end{array}$ & $\begin{array}{c}\text { Neutral } \\
(\%)\end{array}$ & $\begin{array}{c}\text { Agree } \\
(\%)\end{array}$ & $\begin{array}{c}\text { Strongly } \\
\text { Agree } \\
(\%)\end{array}$ \\
\hline Obj & 98 & 2.8 & 1.4 & 17 & 37 & 10 & 21 & 14 \\
Manage & 99 & 3.6 & 1.2 & 5 & 18 & 16 & 34 & 26 \\
Direct & 98 & 3.8 & 1.2 & 4 & 14 & 14 & 36 & 32 \\
\hline
\end{tabular}

Source: Survey applied. 
Observations: Frequencies are displayed as percentages. Percentage values have been rounded and may not add up to $100 \%$.

Table 5 - Descriptive statistics for independent categorical variables

\begin{tabular}{|c|c|c|c|c|c|c|c|c|}
\hline $\begin{array}{c}\text { Variabl } \\
\text { e }\end{array}$ & $N$ & $\begin{array}{c}\text { Mea } \\
\mathrm{n}\end{array}$ & $\begin{array}{c}\text { Standar } \\
\text { d } \\
\text { Deviati } \\
\text { on } \\
\end{array}$ & $\begin{array}{c}\text { Strongly } \\
\text { Disagree } \\
(\%)\end{array}$ & $\begin{array}{c}\text { Disagree } \\
(\%)\end{array}$ & $\begin{array}{c}\text { Neutral } \\
(\%)\end{array}$ & $\begin{array}{c}\text { Agree } \\
(\%)\end{array}$ & $\begin{array}{c}\text { Strongly } \\
\text { Agree } \\
(\%)\end{array}$ \\
\hline $\mathrm{F}_{1}$ & 99 & 4.7 & 0.6 & 0 & 1 & 3 & 24 & 72 \\
\hline $\mathrm{F}_{2}$ & 98 & 2.8 & 1.3 & 14 & 41 & 12 & 17 & 15 \\
\hline $\mathrm{F}_{3}$ & 99 & 3.2 & 1.1 & 5 & 19 & 42 & 14 & 19 \\
\hline $\mathrm{F}_{4}$ & $\begin{array}{c}10 \\
0\end{array}$ & 4.4 & 1.0 & 3 & 6 & 2 & 22 & 67 \\
\hline $\mathrm{F}_{5}$ & $\begin{array}{c}10 \\
0\end{array}$ & 3.0 & 1.2 & 9 & 35 & 13 & 33 & 10 \\
\hline $\mathrm{F}_{6}$ & $\begin{array}{c}10 \\
0\end{array}$ & 2.7 & 1.3 & 14 & 50 & 5 & 18 & 13 \\
\hline $\mathrm{F}_{7}$ & $\begin{array}{c}10 \\
0\end{array}$ & 4.4 & 1.0 & 3 & 5 & 1 & 35 & 56 \\
\hline $\mathrm{M}_{1}$ & 97 & 2.0 & 1.0 & 35 & 47 & 6 & 8 & 3 \\
\hline $\mathrm{M}_{2}$ & 99 & 4.1 & 1.0 & 2 & 8 & 10 & 40 & 39 \\
\hline $\mathrm{M}_{3}$ & 98 & 2.7 & 1.1 & 20 & 34 & 9 & 24 & 12 \\
\hline $\mathrm{M}_{4}$ & 98 & 2.1 & 1.1 & 32 & 42 & 10 & 14 & 2 \\
\hline $\mathrm{M}_{5}$ & 99 & 3.4 & 1.2 & 10 & 19 & 9 & 47 & 14 \\
\hline
\end{tabular}

Source: Survey applied.

Observations: Frequencies are displayed as percentages. Percentage values have been rounded and may not add up to $100 \%$.

Table 6 - Descriptive statistics for independent indicator variables

\begin{tabular}{lrcc}
\hline Variable & $N$ & $\begin{array}{c}\text { No } \\
(\%)\end{array}$ & $\begin{array}{c}\text { Yes } \\
(\%)\end{array}$ \\
\hline Con & 103 & 82.52 & 17.48 \\
Con & 103 & 68.93 & 31.07 \\
Loc & 103 & 52.43 & 47.57 \\
Und & 102 & 35.29 & 64.71 \\
Late & 103 & 85.44 & 14.56 \\
\hline
\end{tabular}

Source: Survey applied.

Observations: Frequencies are displayed as percentages. Percentage values have been rounded and may not add up to $100 \%$. 
Table 7 - Descriptive statistics for other independent variables

\begin{tabular}{lccc}
\hline $\begin{array}{c}\text { Variab } \\
\text { le }\end{array}$ & $N$ & Mean & Standard Deviation \\
\hline Inc & 101 & $32,029.70$ & $38,292.81$ \\
Mills & 103 & 1.75 & 0.87 \\
Year & 103 & 32.56 & 18.48 \\
Sales & 102 & 72.34 & 33.63 \\
\hline
\end{tabular}

Source: Survey applied.

Observations: Frequencies are displayed as percentages. Percentage values have been rounded and may not add up to $100 \%$.

\section{Empirical Methodology}

Our empirical strategy was to evaluate the factors that influence contract-holders to no longer be a part of contract agreements $(O b j)$, then we evaluate the factors that changed how producers feel about their contracts and their perception of whether mills fulfilling their part of the contractual agreements (Fulfill). Finally, the study assessed the impacts on producer trust in the mill's management (Manage) and their trust in the mill's direction fulfilling their promises (Direct).

The analytical approach was designed to first identify factors that change producers' view on contracts, then progressed to identify factors changing their perception of contract fulfillment and producer trust. Factors that were identified as significant across multiple models were of the most interest for promoting support for contract farming. Prior to estimate the dependent variable Fulfill was recoded in reverse order so that "Yes, a great deal" was a 5 and "No, never" was a 1, to align with the ordering of the other dependent variables. Given the categorical nature of the variables, the assessment of the different independent variables was conducted using ordered logistic regression models (McKelvey and Zavoina, 2010). Due to the wide use of ordered logistic regression in the literature, we refer the reader to Greene (2012) for details on model specification and estimation. The signs of estimated coefficients from the models can be interpreted as increasing (decreasing) the probability of being placed in a higher category if the coefficient is positive (negative). For example, a negative coefficient would indicate that as the associated variable increases the more likely the producer is to strongly disagree or to mean "no, never".

Statistical analyses were conducted using STATA. Supply contracts were set as the base case among contract type variables (Con), and Goiás was set as the base case for 
the location variable $(L o c)$. Statistical significance of the parameter estimates was assessed at $1 \%, 5 \%$, and $10 \%$ levels of significance.

\section{Results}

Results are presented following the ordering of the dependent variables of interest as discussed in section 2.2.

\section{Producer Perceptions' on Need for Contractual Agreements}

Table 8 provides the parameter estimates and p-values for the ordinal regression, predicting producer views about their need for contractual agreements $(O b j)$. The model has a pseudo- $R^{2}$ of 0.15 . Six of the explanatory variables were found to be statistically significant. The results indicate an aversion to dependence on contracts signed with a local sugarcane mill to produce sugarcane. In fact, the more producers agreed that they preferred to sign a contract with a cooperative $\left(\mathrm{F}_{2}\right)$, the less likely they were to agree of the need to depend on a contract directly with a local mill. This result may indicate producer's preferences to work through cooperatives, which are likely to provide much better bargaining and negotiating positions for a producer in relation to the mill. Producers that prefer to sign a contract with national companies $\left(\mathrm{F}_{3}\right)$ would rather not have to depend on a contract with a sugarcane mill, many of which are partially owned by foreign corporations $^{2}$. Model results indicate the more producers understand about their contract (Und) and the larger percentage of their sales that come from sugarcane production (Sales), the more likely producers were to prefer not to operate under a contract. Producers may feel that contracts limit their flexibility and the value they could receive for their sugarcane, which may become more important as farmers rely more on sugarcane production for their livelihood. Producers that feel they have seen a decrease in profit from entering into a contractual relationship with a mill $\left(M_{1}\right)$ have less of a desire to be operating under a contract. This relates to D'Silva et al. (2009) findings that higher profits change perception towards contract farming. Only farms that have been in operation for a significant period appeared to prefer to produce under a contract. Years on farming was found to have a positive relationship with the producers' perceived need for a contractual

\footnotetext{
${ }^{2}$ In 2013 around a third of Brazil's sugar and ethanol production came from foreign owned mills (Oliveira, 2013).
} 
relationship with the mill. It may be that older farms, who have operated in the Cerrado for a significant period may perceive sugarcane as a riskier crop option when compared to other crops.

Table 8 - Ordered logit model, producer view on contract agreements

\begin{tabular}{|c|c|c|}
\hline Variable & Parameter estimate & Standard error \\
\hline Con $_{L R}$ & -0.53 & 0.63 \\
\hline $\operatorname{Con}_{\mathrm{AP}}$ & 0.81 & 0.65 \\
\hline $\operatorname{Loc}_{M S}$ & 0.11 & 0.53 \\
\hline Inc & 0.0000045 & 0.0000065 \\
\hline Mills & -0.17 & 0.27 \\
\hline $\mathrm{F}_{1}$ & -0.54 & 0.42 \\
\hline $\mathrm{F}_{2}$ & -0.42 & $0.18 * *$ \\
\hline $\mathrm{F}_{3}$ & -0.47 & $0.20 * *$ \\
\hline $\mathrm{F}_{4}$ & -0.25 & 0.23 \\
\hline $\mathrm{F}_{5}$ & -0.15 & 0.20 \\
\hline $\mathrm{F}_{6}$ & 0.23 & 0.20 \\
\hline $\mathrm{F}_{7}$ & -0.26 & 0.29 \\
\hline Und & -0.76 & $0.25 * * *$ \\
\hline Late & 0.41 & 0.60 \\
\hline $\mathrm{M}_{1}$ & -0.61 & $0.28 * *$ \\
\hline $\mathrm{M}_{2}$ & -0.21 & 0.28 \\
\hline $\mathrm{M}_{3}$ & 0.16 & 0.17 \\
\hline $\mathrm{M}_{4}$ & -0.015 & 0.23 \\
\hline $\mathrm{M}_{5}$ & 0.17 & 0.18 \\
\hline Year & 0.022 & $0.013^{*}$ \\
\hline Sales & -0.019 & $0.0081 * *$ \\
\hline \multicolumn{3}{|l|}{ Threshold } \\
\hline Strongly Agree & -12.69 & $3.48 * * *$ \\
\hline Agree & -11.085 & $3.43 * * *$ \\
\hline Neutral & -10.51 & $4.41 * * *$ \\
\hline Disagree & -8.21 & $3.33 * * *$ \\
\hline \multicolumn{3}{|c|}{ Model Fit Statistics } \\
\hline Log Likelihood & \multirow{2}{*}{\multicolumn{2}{|c|}{$\begin{array}{c}-118.16 \\
0.15\end{array}$}} \\
\hline Pseudo R-Squared & & \\
\hline
\end{tabular}

Note: Reference group was "Strongly Disagree"

*: Significant at the 0.10 level. **: Significant at the 0.05 level. ***: Significant at the 0.01 level. 


\section{Producers' Perception of Contract Fulfillment}

Table 9 shows the factors that influence producers' perceptions regarding contract fulfillment (Fulfill). That is, if they agree that the mill is fulfilling the agreement. The pseudo- $\mathrm{R}^{2}$ for the model was 0.20 . The model identified a significant positive relationship between perceived return under their contract and contract fulfillment. As producers agree more strongly that they have received a fair value for their sugarcane from the mill $\left(M_{5}\right)$, the more they felt the mill was fulfilling their end of the contract. This result emphasizes the strong economic incentives of being satisfied with one's contractual relationship. Furthermore, the larger the percentage of sales that come from sugarcane production (Sales), the more producers felt the mills were fulfilling their contracts, further linking the economic outcome from sugarcane production and perceived contract fulfillment. Tardiness on payments, though, were linked with producers' feeling that the contracts were not fulfilled, as might be expected. When a history of receiving a late payment (Late) was present, the producer was more likely to agree that the mill was not fulfilling their part in the contract. Finally, the model identified that producers from Mato Grosso do Sul (MS), when compared to their Goiás (GO) counterparts, were more likely to feel fulfilled with their contracts. Nearly $40 \%$ of the farmers and landowners interviewed in Goiás (GO) were concerned with the financial stability of the mill (Sant'Anna, Granco, et al. 2016).

Table 9 - Ordered logit model, producers' perception of contract fulfillment

\begin{tabular}{lcc}
\hline \multicolumn{1}{c}{ Variable } & Parameter Estimate & Standard Error \\
\hline Con $_{\mathrm{LR}}$ & 0.11 & 0.94 \\
Con $_{\mathrm{AP}}$ & 0.12 & 1.0098 \\
Loc & -1.72 & $0.83^{* *}$ \\
Inc & -0.0000094 & 0.0000099 \\
Mills & 0.16 & 0.40 \\
$\mathrm{~F}_{1}$ & -0.34 & 0.67 \\
$\mathrm{~F}_{2}$ & 0.35 & 0.25 \\
$\mathrm{~F}_{3}$ & 0.059 & 0.33 \\
$\mathrm{~F}_{4}$ & 0.14 & 0.39 \\
$\mathrm{~F}_{5}$ & -0.31 & 0.35 \\
$\mathrm{~F}_{6}$ & -0.073 & 0.30 \\
$\mathrm{~F}_{7}$ & 0.38 & 0.48 \\
$\mathrm{Und}_{\text {Lnd }}$ & -0.52 & 0.37 \\
Late $_{M_{1}}$ & 1.71 & $0.73^{* *}$ \\
$\mathrm{M}_{2}$ & 0.16 & 0.43 \\
$\mathrm{M}_{3}$ & 0.37 & 0.41 \\
\end{tabular}


Threshold

No, never

amount

Model fit statistics

Log Likelihood

Note: Reference group was "Yes, a great deal"

*: Significant at the 0.10 level. **: Significant at the 0.05 level. ***: Significant at the 0.01 level.

\section{Producers' Trust of a Mill's Management and Direction}

The following section discusses the results for the two models referring to producer trust of the mill and in the mill's direction in fulfilling its promises. Table 10 identifies 6 independent variables that significantly affect producer's trust in a mill's management (Manage). The estimated order logit model has a pseudo- $\mathrm{R}^{2}$ of 0.27 . Results indicate that trust is positively influenced by communication with the mill, perceptions from fellow producers about the mill, and the mill's origin. Having a good relationship with the mill $\left(F_{1}\right)$ and whether a producer can communicate easily with the mill $\left(M_{3}\right)$ have a positive impact on producers' trust in the mill. Relationship and trust appear to go hand in hand. Schipmann and Quaim (2011) had already highlighted in their study the linkages between trust and producer and contractor relations. Nationally owned mills $\left(F_{3}\right)$ have a higher likelihood of gaining producers' trust. This may be due to the case that farmers may find it easier to gain reliable information on the mill if it is nationally owned. In addition, fellow farmers may have already worked with a nationally owned company or may know of people who have. There exists a strong peer effect too, as fellow local producers' relationships with the local mill can affect a producer's trust in the mill. The more a producer believes that farmers in the region cannot trust a local mill $\left(F_{5}\right)$ the more likely they, themselves will also not trust the mill. Finally, contracts that are hard to 
procure $\left(F_{6}\right)$ and limited bargaining power $\left(F_{7}\right)$ reduce the belief that producers or landowners will trust mill management.

Table 10 - Ordered logit model, trust of a mill's management

\begin{tabular}{|c|c|c|}
\hline Variable & Parameter Estimate & Standard Error \\
\hline $\operatorname{Con}_{L R}$ & 0.42 & 0.65 \\
\hline $\operatorname{Con}_{\mathrm{AP}}$ & -0.72 & 0.68 \\
\hline $\operatorname{Loc}_{\mathrm{MS}}$ & 0.22 & 0.59 \\
\hline Inc & 0.0000096 & 0.0000070 \\
\hline Mills & -0.29 & 0.29 \\
\hline $\mathrm{F}_{1}$ & -0.79 & $0.44 *$ \\
\hline $\mathrm{F}_{2}$ & 0.11 & 0.18 \\
\hline $\mathrm{F}_{3}$ & -0.40 & $0.21 *$ \\
\hline $\mathrm{F}_{4}$ & -0.39 & 0.26 \\
\hline $\mathrm{F}_{5}$ & 0.91 & $0.24 * * *$ \\
\hline $\mathrm{F}_{6}$ & 0.53 & $0.21 * * *$ \\
\hline $\mathrm{F}_{7}$ & 0.76 & $0.30 * *$ \\
\hline Und & -0.20 & 0.26 \\
\hline Late & 0.50 & 0.59 \\
\hline $\mathrm{M}_{1}$ & -0.41 & 0.28 \\
\hline $\mathrm{M}_{2}$ & -0.31 & 0.31 \\
\hline $\mathrm{M}_{3}$ & 0.36 & $0.18 * *$ \\
\hline $\mathrm{M}_{4}$ & -0.37 & 0.25 \\
\hline $\mathrm{M}_{5}$ & -0.24 & 0.19 \\
\hline Year & -0.0077 & 0.013 \\
\hline Sales & -0.0027 & 0.0074 \\
\hline \multicolumn{3}{|l|}{ Threshold } \\
\hline Strongly Agree & -4.22 & 3.63 \\
\hline Agree & -1.86 & 3.59 \\
\hline Neutral & -0.51 & 3.59 \\
\hline Disagree & 2.35 & 3.65 \\
\hline \multicolumn{3}{|c|}{ Model fit statistics } \\
\hline Log Likelihood & \multicolumn{2}{|c|}{-99.06} \\
\hline Pseudo R-Squared & \multicolumn{2}{|c|}{0.27} \\
\hline
\end{tabular}

There are three explanatory variables that significantly affect producers' trust that the mill's will fulfill its promises (Direct) (Table 11). The estimated model had a pseudo$\mathrm{R}^{2}$ of 0.22 . Similar to the results presented above in relation to a producer's trust in the mill, a good relationship with the mill $\left(F_{l}\right)$ and the knowledge that farmers in the region 
trust the mill $\left(F_{5}\right)$ increase producers' trust in the direction the mill is going. Thus, better relationships between farmers and mills lead to more trust in mills' management and that it will make good on its promises. Since good relationships are usually based on effective communication, difficulties in communicating $\left(M_{3}\right)$ lead to less of a likelihood in trusting the mill's direction. Therefore, if mills want to increase farmer's trust they should focus on effective communications and relationships with local producers.

Table 11- Ordered logit model, trust of a mill's direction

\begin{tabular}{|c|c|c|}
\hline Variable & Parameter Estimate & Standard Error \\
\hline Con $_{L R}$ & -0.51 & 0.70 \\
\hline $\operatorname{Con}_{\mathrm{AP}}$ & -0.32 & 0.67 \\
\hline $\operatorname{Loc}_{\mathrm{MS}}$ & -0.92 & 0.58 \\
\hline Inc & -0.0000019 & 0.0000077 \\
\hline Mills & -0.41 & 0.28 \\
\hline$F_{1}$ & -0.87 & $0.47 *$ \\
\hline $\mathrm{F}_{2}$ & 0.050 & 0.18 \\
\hline $\mathrm{F}_{3}$ & -0.21 & 0.21 \\
\hline $\mathrm{F}_{4}$ & -0.19 & 0.23 \\
\hline $\mathrm{F}_{5}$ & 0.83 & $0.24 * * *$ \\
\hline $\mathrm{F}_{6}$ & -0.041 & 0.20 \\
\hline $\mathrm{F}_{7}$ & 0.082 & 0.28 \\
\hline Und & -0.16 & 0.27 \\
\hline Late & 0.54 & 0.61 \\
\hline $\mathrm{M}_{1}$ & -0.20 & 0.29 \\
\hline $\mathrm{M}_{2}$ & -0.27 & 0.31 \\
\hline $\mathrm{M}_{3}$ & 0.36 & $0.18 *$ \\
\hline $\mathrm{M}_{4}$ & -0.30 & 0.26 \\
\hline $\mathrm{M}_{5}$ & -0.13 & 0.19 \\
\hline Year & 0.0056 & 0.012 \\
\hline Sales & 0.0038 & 0.0070 \\
\hline \multicolumn{3}{|l|}{ Threshold } \\
\hline Strongly Agree & -6.75 & 3.98 \\
\hline Agree & -4.27 & 3.93 \\
\hline Neutral & -3.18 & 3.93 \\
\hline Disagree & -0.93 & 3.96 \\
\hline \multicolumn{3}{|c|}{ Model fit statistics } \\
\hline Log Likelihood & & \\
\hline Pseudo R-Squared & & \\
\hline
\end{tabular}

Note: Reference group was "Strongly Disagree"

*: Significant at the 0.10 level. **: Significant at the 0.05 level. ***: Significant at the 0.01 level. 


\section{Conclusion}

Increasing dependency on contractual agreements amongst supply chain members has been an effective solution for increasing vertical coordination in agricultural industries (Vavra, 2009). However, questions have arisen about how producers, who are lower in the supply chain, perceive their relationship with contractors and if they are benefitting from these partnerships (Bijman, 2008). Farmers are taking on more contract agreements, which is potentially advantageous for industries in new areas of agricultural frontiers, but this may be disadvantageous to producers who may have limited bargaining power. Beneficial contractual relationships and perceptions are essential for mills to maintain favorable relationships with sugarcane producers and ensuring the longevity of sugarcane production. To this extent, it is important to understand the factors affecting producers view on contracts (e.g. their belief on contract fulfillment and their trust in the mill).

Results indicate that in general producers do not like signing contracts. Even when working with nationally owned mills, which has positive impacts on trust, or when signing a contract as part of a cooperative. It maybe that farmers prefer more flexibility and autonomy in their activities (Hudson and Lusk, 2004). After all, it seems reasonable that farmers should prefer contracts, given the perennial nature of sugarcane and the high initial investment costs it requires. Echánove and Steffen (2004) argue that producers were agreeing to contracts not with consent, but rather out of financial limitations. This argument that farmers are entering into contracts due to the lack of alternatives for financing, technical assistance, and access to markets is not unique. In Goiás, Picanço Filho and Marin (2012) argue that farmers were, at times, being pressured into contracts they did not benefit them. When a producer's livelihood depends on a contract it can eliminate their ability to negotiate and limit their bargaining power, discouraging their trust in the enterprise they are dealing with. Therefore, having more transparency and knowledge about contractual obligations and relationships could be a first step towards facilitating contract negotiation and acceptance.

Producer's trust of the institutions they are involved with is of significant importance for their continued partnership and support. Determining the factors that change a producer's trust of a mill's management and direction are essential for developing transparency and efficiency between the parties. Significant factors 
contributing to producers' trust of a mill's management are the producers' direct relationship with the mill and the perception of the relationship other fellow producers have with the mill. Clear channels of communication and a strong relationship between the mill and the producer are key factors in determining the degree of trust. If the relationship has been strained by difficult contract negotiations or difficulties in communication, then the farmer is less likely to trust the mill. Discouraged producers could lead to potential issues for sugarcane mills, such as producers desiring to not to fulfill their contract obligations, not renewing contracts, or being enticed by other local mills. This could have significant repercussions to the expansion of sugarcane into the Cerrado.

Additionally, results point to the importance of peer effects. The more fellow producers distrust the local mill the more likely the producer will distrust the mill. Therefore, those mills that make efforts to increase their credibility with producers must think of the entire community, since their beliefs may be communal. This result may explain why mills occasionally seek to provide improvements to the local town and community. Sant'Anna et al. (2016) found that local community residents usually associated a mill's arrival in a region with increases in welfare to the community.

Although profitability may positively impact a producer's willingness to sign a contract it may not have the same impact on their trust in the mill. Results indicate that producers who found it difficult to communicate with the mill were less likely to trust a mill's direction. Improving communication is a significant factor that can improve both trust in the mill and trust in the mill's direction. Gaining support in both leadership and vision for the sugarcane mill can greatly improve producer and contractor morale and productivity.

Trust in mills and willingness to enter into contracts are essential to maintain sugarcane and ethanol expansion in the Brazilian Cerrado given sugarcane's geographic, temporal and physical asset specificities. Contracts provide mills access to sugarcane supply or to land for sugarcane production. Results from this study help mills understand producer's demands and needs, and provide suggestions on how mills can improve on making producers feel supported and heard. It appears that mills that wish to increase producers' trust and willingness to enter into contracts, should invest in increasing transparency, ensuring fair payments for sugarcane, facilitating communication and contract negotiation, and making sure they maintain good relationships with local 
communities in the region. Mills may want to seek more involvement in the community if they wish to increase their relationship with farmers and gain their trust. Further studies still need to be conducted, though, to understand what specific avenues and strategies would be most effective in accomplishing these goals.

Acknowledgements: This work was supported by the National Science Foundation, USA [NSF BCS-1227451 and NSF SMA-1359082]. Any opinions, findings, and conclusions or recommendations expressed in this paper are those of the authors and do not necessarily reflect the views of the National Science Foundation. Work was performed while Ana Claudia Sant'Anna was a Ph.D. candidate at Kansas State University.

\section{References}

BIJMAN, J. (2008). Contract farming in developing countries: an overview. Wageningen University, Department of Business Administration.

CONAB - Companhia Nacional de Abastecimento. 2013. Perfil do Setor do Açúcar e do Etanol no Brasil. Brasília: CONAB. Available at: www.conab.gov.br/OlalaCMS/uploads/arquivos/ 13_10_02_11_28_41_perfil_sucro_2012.pdf. (Accessed July 12, 2017)

D'SILVA, J. L., Uli, J., \& Samah, B. A. (2009). “A review of contract farming and factors that impinge youths acceptance to contract farming". European Journal of Social Sciences, 11(2), 328-338.

ECHÁNOVE, F., \& Steffen, C. (2005). Agribusiness and farmers in Mexico: the importance of contractual relations. The Geographical Journal, 171(2), 166-176.

GREENE, W.H. (2012). Econometric Analysis. 7th ed. Upper Saddle River, NJ, USA: Prentice Hall.

LUSK, J.L., and D. Hudson. (2004). "Willingness-to-pay estimates and their relevance to agribusiness decision making." Review of Agricultural Economics 26(2):152-169.

IBGE - Brazilian Institute of Statistics and Geography. 2014. "Produção Agrícola Municipal (PAM).” Available at: http://www.sidra.ibge.gov.br/. (Accessed July 12, 2017)

IBGE - Brazilian Institute of Statistics and Geography. 2006. "Censo Agropecuario 2006." Available at: http://www.sidra.ibge.gov.br/. (Accessed July 12, 2017)

MORAES, M.A.F.D. de, and D. Zilberman. (2014). "Production of ethanol from sugarcane in brazil: from state intervention to a free market." Springer Science \& Business Media.

MCKELVEY, R. D., and Zavoina, W. (1975). A statistical model for the analysis of ordinal level dependent variables. Journal of mathematical sociology, 4(1), 103-120. 
OLIVEIRA, G., 2013. Estrangeiros são a nova geração de usineiros. O Globo. Available at: https://oglobo.globo.com/economia/estrangeiros-sao-nova-geracao-de-usineiros-8232513.

(Accessed Sep. 2017)

PICANÇO FILHO, A.F., and J.O.B. Marin. 2012. "Sugarcane Supply Agreement: The Power Asymmetry Between Agents." INTERAÇÕES 13 (2): 191-202.

PICANÇO FILHO, A.F. 2012a. "The Sugar Cane Political Network and its Power Resources in The Goiás State, Brazil.” Pesquisa Agropecuária Tropical 42 (2): 189-97.

PICANÇO FILHO, A.F. 2010. "Contratos Agrários na Agroindústria Canavieira em Goiás: Legalidades e Conflitos." MS thesis, University of Goias.

PROCANA. 2013. Brazilian Sugar and Ethanol Guide 2013. Ribeirão Preto: ProCana Brasil.

RUDORFF, B.F.T., D.A. Aguiar, W.F. Silva, L.M. Sugawara, M. Adami, and M.A. Moreira, M.A., 2010. "Studies on the Rapid Expansion of Sugarcane for Ethanol Production in São Paulo State (Brazil) Using Landsat Data.” Remote Sensing 2 (4), 1057-1076.

SANT'ANNA, A. C., Bergtold, J., Caldas, M., and Granco, G. (2016). Analyzing sugarcane production contracts in Brazil: What do the farmers really want? In 2016 Annual Meeting, July 31-August 2, 2016, Boston, Massachusetts (No. 235655). Agricultural and Applied Economics Association.

SANT'ANNA, A. C., G. Granco, J. Bergtold, M.M. Caldas, T. Xia, P. Masi, T. Link, and W. Lorenzani. (2016) "Chapter 13: The Challenges of the Sugarcane Expansion: How do Producers and Land Owners Think and Act?" In: Forty Years of Ethanol in Brazil: Hide or Confront the Crises? Santos, G. (eds) Brasilia: IPEA, 2016.

SANT'ANNA, A.C., A. Shanoyan, J.S. Bergtold, M.M. Caldas, and G. Granco. (2016). "Ethanol and sugarcane expansion in Brazil: what is fueling the ethanol industry?" International Food and Agribusiness Management Review 19(4):163-182.

SCHIPMANN, C., and Qaim, M. (2011). Supply chain differentiation, contract agriculture, and farmers' marketing preferences: The case of sweet pepper in Thailand. Food Policy, 36(5), 667677.

SINGH, S. (2000). Theory and practice of contract farming: a review. Journal of social and economic development. Retrieved from http://203.200.22.249:8080/jspui/bitstream/123456789/9226/1/JSED_V2-I2_228-246.pdf

VAVRA, P. (2009), "Role, Usage and Motivation for Contracting in Agriculture", OECD Food, Agriculture and Fisheries Working Papers, No. 16, OECD Publishing. doi: $10.1787 / 225036745705$ 